\title{
Clasificación de los restos de la lengua guanche según su grado de integración en español
}

\author{
Classification of the remains of the language original inhabitant of the \\ Canary Isles according to its degree of integration into Spanish language
}

\author{
Marcial Morera \\ Instituto Universitario de Lingüística "Andrés Bello" \\ Universidad de La Laguna
}

RESUMEN: Desde el punto de vista de su mayor o menor integración en las estructuras fónicas, gramaticales y léxicas de la lengua española, las palabras y frases que se conservan en el habla canaria de la desaparecida lengua que hablaba la antigua población de las Islas pertenecen a tres clases radicalmente distintas: préstamos tradicionales, que entraron en el habla insular por vía popular; préstamos terminológicos, que entraron por vía culta; y glosas guanches, que son meras citas de palabras o frases de la lengua de los aborígenes canarios hechas por cronistas y eruditos.

Palabras clave: etimología, semántica, gramática, fonética.

ABSTRACT: From the point of view of their major or minor degree of integration in the fonetic, grammatical and semantic spanish structures, words and phrases of the language spoken by the ancient population of Canary Island that survive in Canary Spanish can be classified in three different types: traditional borrowings, introduced by a popular way; terminological borrowings, introduced by learning one; and foreign words and phrases, that are simple citations introduced in Spanish by chroniclers and scholars.

Keywords: etymology, semantics, grammar, phonetics. 
Aunque, por lo general, los restos que sobrevivieron en el español de Canarias de la desaparecida lengua bereber ${ }^{1}$ que hablaba la antigua población de las Islas Canarias ${ }^{2}$ se suelen considerar material lingüístico más o menos homogé$n^{n} o^{3}$, la verdad es que se trata de palabras y expresiones que pertenecen a tipos idiomáticos bastante diferenciados, si tomamos en consideración las transformaciones que las mismas experimentaron para adaptarse a la lengua que las acogió, y que las ha alejado en mayor o menor medida de su forma originaria. Di-

${ }^{1}$ En contra de los estudiosos que han relacionado el guanche con las lenguas semíticas, el hebreo o el vasco, desde la época de los cronistas insulares se sabe que la lengua o lenguas que hablaba la antigua población de las Islas Canarias eran de la familia camito-bereber. "En estas tres islas (Lanzarote, Fuerteventura y Gran Canaria) — señala Abreu Galindo (1977: 32-33) — 1lamaban los naturales a la leche aho; al puerco, ylfe; a la cebada, tomosen; y ese mismo nombre tienen los alárabes y berberiscos." Es la hipótesis que sostiene también G. Glas (2010: 197-204). Un examen amplio del desarrollo de estas ideas puede verse en Díaz Alayón, Castillo y Díaz Padilla (1995: 15-72).

${ }^{2}$ Problema arduo es el de la procedencia concreta de la vieja población canaria. ¿Vino de la parte de Marruecos más próxima a Canarias, o vino de más al este? Nadie lo sabe con seguridad. Abreu (1977: 31-32) fue el primero en sugerir que podría proceder de la zona de Marruecos que se encuentra frente a las costas del archipiélago. Posteriormente, se ha pensado en la posibilidad de que haya venido de las zonas que ocupan hoy Argelia o Túnez. Lamentablemente, ninguna de estas hipótesis ha sido demostrada de forma concluyente. Como es natural, tampoco sabemos nada seguro de la cronología de la lengua que hablaban los bereberes insulares. Para unos, se trata de una variante muy antigua del bereber. Para otros, las diferencias entre el guanche y sus hermanas continentales no son tan abismales como afirman algunos. No queremos ocultar que ambas circunstancias relativizan todo paralelismo que se establezca entre las palabras de la lengua guanche y las correspondientes de sus hermanas continentales.

${ }^{3}$ Respecto de si hablaban una o varias lenguas, nada se sabe con seguridad. Por lo menos desde Viera (1982: 131), se viene diciendo que toda la población preeuropea de las Islas Canarias hablaba una misma lengua, aunque con diferencias en cada uno de los territorios insulares. Los estudiosos posteriores no han hecho otra cosa que acatar el sensato parecer de Viera. Así, para Berthelot (1978: 116-117), "los antiguos habitantes de las Islas Canarias hablaban diversos dialectos, derivados todos evidentemente de una lengua madre, si se juzga al menos por los catálogos de palabras que los historiadores nos han transmitido. Estos catálogos distribuidos por series, según los dialectos de cada isla, ofrecen analogías notables en la raíz de las palabras, así como en su construcción. Se notan varias palabras idénticas que se usaban en todo el archipiélago para expresar una misma cosa, y esta observación, dando más valor al principio fundamental de una lengua madre, cuyas reminiscencias tradicionales se vuelven a encontrar en las diversas jergas, suministra igualmente una prueba de la comunidad de origen de los insulares que las hablaban. El estado de aislamiento en que vivían los antiguos habitantes de las Canarias, por la imposibilidad de comunicarse de una isla a otra, dio lugar sin duda a las modificaciones del idioma". Glas (2010 [1764]: 197-204) fue el primero en establecer una clasificación por islas de las palabras guanches que se conservaron en español. ¿Qué rasgos concretos caracterizaban a cada una de las hablas bereberes de las islas? A pesar de las suposiciones de algunos estudiosos y de la charlatanería de los diletantes, nada sabemos con seguridad respecto de tan complicado asunto, sobre el que solamente los verdaderos especialistas en filología e historia bereberes podrían arrojar alguna luz. Aunque en distintas épocas, estos dialectos insulares de la misma lengua bereber debieron de desaparecer definitivamente hacia finales del siglo XVI, por la presión de la lengua española, según los cronistas insulares. 
lucidar este problema de la dialectología canaria constituye el modesto propósito del presente artículo.

Para empezar, hay que decir que en el habla canaria tenemos palabras guanches más o menos complejas, como:

temi 'punto culminante, extremo, linde, con predominio de verticalidad' (Sabir) ${ }^{4}$, agrur 'lugar cercado' (Sabir), Tamarssit 'nombre de un lugar de la isla de Gran Canaria' (Sabir), Tazart (de t-azar-t 'higuera') 'nombre de un lugar de la isla de Gran Canaria' (Sabir), Tildi 'nombre de un lugar de la isla de Gran Canaria' (Sabir), buffi 'sopa gruesa elaborada a base de harina de cebada' (Sabir), taynast 'especie de planta de flores azules grandes' (Sabir), tagmemt 'pequeña porción de alimento que se echa a la boca' (Sabir), Tinirife (de ti-n-irifi 'la del calor') 'nombre de la isla de Tenerife' (Sabir), inken 'piedra del hogar' (Sabir), tabrayt 'herida' (Sabir), tawwunt 'piedra' (Sabir), igider 'quebrantahuesos' (Sabir), tirufin 'granos de maíz, trigo o cebada tostados' (Sabir), Asif (de asif 'río') 'nombre de un barranco de la isla de Gran Canaria' (Sabir) $)^{5}$, Azugguag (de azugguag 'rojo') 'nombre de un lugar de la isla de Gran Canaria' (Sabir), tacat 'pendiente' (Sabir), iris 'charco' (Sabir), Tagant (de tagant 'selva') 'nombre de un lugar de la isla de La Palma' (Sabir), Taghat (de taghat 'cabra') 'nombre de un lugar de la isla de Fuerteventura' (Sabir), Yesk (de yesk 'cuerno') 'nombre de un punto de la isla de Tenerife' (Sabir), irifi 'calor, fuego, sequedad' (Sabir), walden (derivado de la raíz $l d$ 'mamar' con el sufijo intensivo $-e n^{6}$ ) 'calostro'(Louft) per-n-inken 'lagarto de las piedras' (Louft), Amnay (de a-m-nay 'el lugar desde el que se ve') 'nombre de un lugar de la isla de Fuerteventura' (Louft), Chimich (de $t$-imi-t 'la boca') 'nombre de un lugar de la isla de Tenerife' (Louft), Argnwin (de $a$-arg-n-win 'la tierra de aquellos') 'nombre de un lugar de la isla de Gran Canaria' (Louft), t-ghrs '(animal) destinado al sacrificio' (Louft), wa-n-il 'lo de libre' (Louft), Tetir (de tet 'fuente' e ir 'valle') 'nombre de un lugar de la isla de Fuerteventura' (Louft), tebebi 'nombre de una especie de planta' (Loutft), ilmul 'mecer' (Loutf), sken (de sk 'piedra' y el sufijo colectivo -en) 'lugar cerrado con pared de piedra', 'adoratorio'

\footnotetext{
${ }^{4}$ Nos referimos a Ahmed Sabir (2001). En todo caso, hay que tener en cuenta que las palabras que citamos no son en realidad palabras de la lengua guanche, que es lengua desaparecida, como dijimos, sino palabras de sus hermanas bereberes del norte de África, con las que acaso coincidirían en mayor o menor medida las insulares. Se trata, por tanto, solo de hipótesis más o menos verosímiles. De ahí que todas las elucubraciones o conjeturas que se hagan a partir de ellas deban tomarse con mucha cautela.

${ }^{5}$ Obviamente, al adaptarse a la lengua española, muchos de estos nombres, que llevaban aparejada significación referida a accidentes del terreno, procedente de los nombres comunes que les servían de base, perdieron este componente semántico y se convirtieron en ciegos identificadores de los nombres comunes españoles barranco, montaña, llano, degollada, etc., que acompañan.

${ }^{6}$ Por lo general, los nombres bereberes o amazighios están constituidos por una raíz léxica de una o más consonantes portadora de una significación abstracta y las marcas de género (masculino o femenino), número (singular o plural) y estado (libre o dependiente).

${ }^{7}$ Louft (2007: 69-112) y Louft (2008).
} 
(Louft), wa-n-Chinec 'el de Chinec' (Louft), timist 'boca pequeña' (Louft), Adeyahamen (de adey 'abajo' y ahamen 'aguas') 'nombre de un lugar de La Palma' (Louft), Adege (o Edege) (de edeg 'lugar') 'nombre de un lugar de Tenerife y otro de Fuerteventura' (Cubillo), Tindaya (de ti-n-daya 'las de abajo') 'nombre de un lugar de Fuerteventura', takfait 'leche fresca' (Wölfel), tagses 'nombre de una gramínea' (Wölfel), Arautapala 'nombre de un valle de Tenerife', etc.,

Que, tras un proceso evolutivo ininterrumpido en boca del pueblo - que empezó desde el mismo momento en que los españoles pusieron sus pies por primera vez en las islas y entraron en contacto con los indígenas-, terminaron convirtiéndose en las palabras primitivas del habla canaria:

time (etime, letime) 'orilla o borde del acantilado', goro 'pequeño corral redondo de piedra', Tamaraceite ${ }^{9}$, Tasarte, Telde, gofio 'harina elaborada a base de granos de cereales tostados' ${ }^{10}$, tajinaste 'determinada especie vegetal', gamame 'porción de gofio en polvo que se coge con los dedos o con una cuchara y que se usa como tapa para acompañar el vino', Tenerife, tenique (chenique, chínique) ${ }^{11}$ 'cada una de las piedras del hogar', teberite 'marca consiste en un corte largo paralelo al eje longitudinal de la oreja de la cabra', tabona 'piedra de obsidiana afilada', guirre 'ave rapaz semejante al buitre, alimoche" ${ }^{12}$, tafeña (chafeña) 'millo, cebada o trigo tostado', (Barranco de) Anzofé, Azuaje, Taca 'nombre de un lugar de la isla de Fuerteventura' y Taco 'nombre de un lugar de la isla de Tenerife', eres 'hoyo o poceta en las rocas del fondo del barranco', Tacande, Tesjuate, Yesgue, arife 'calor fuerte' (acaso presente también en los topónimos Tenerife, Terife, Arafo), beletén 'leche que da la cabra los primeros días después de parida',

\footnotetext{
${ }^{8}$ La información léxica del español de Canarias que se maneja aquí procede de Morera (2007).

9 Como se ha señalado siempre, los nombres propios de lugar constituyen el aporte más importante de la lengua canaria prehispánica al español hablado en las islas. Precisamente por ello resulta tan particular la toponimia canaria (y los gentilicios derivados de ella) dentro del mundo hispánico. Denominaciones como Fayagua, Fimanpaire, Temejereque, Guayedra, Tenerife, Finiquineo, Tesejerague, Taburiente, Taguluche, Tacoronte, tacorontero, Taganana, tagananero, Giniginámar, Teror, terorense, Maxorata, majorero, etc., resultan tan exóticas desde el punto de vista del significante, que difícilmente pueden pasar desapercibidas al oído de un hispanohablante común.

${ }^{10}$ Que la palabra canaria gofio proceda del bereber buffi 'sopa gruesa elaborada a base de harina de cebada' es una mera hipótesis, en absoluto concluyente.

${ }^{11}$ Esta variante debía de estar presente en la misma lengua guanche, pues, en posición inicial, las consonantes / $/ \mathrm{y} / \mathrm{t} / \mathrm{se}$ comportan como variantes de expresión en muchas lenguas bereberes. Vid. al respecto Werner Vicychl (1952: 167-204). Difícil, si no imposible, es determinar el grado de desarrollo que tenía el fenómeno en cada una de las hablas guanches del archipiélago. Actualmente, por lo menos, los guanchismos con $/ \mathrm{t}] /$ tienen más presencia en las islas occidentales que en las islas orientales.

12 Alvar (1959: 186) sugirió que esta voz podría no ser guanche, sino románica, relacionada con la voz salmantina de origen onomatopéyico guirre 'vencejo', recogida por Lamano (1959: 186). El abismo semántico existente entre ambas voces hace poco verosímil esta hipótesis.
} 
perinquén (perenquén, pracan ${ }^{13}$ ) 'salamanquesa, reptil saurio', Amanay, Chimiche, Arguineguín, tajorase 'macho cabrío joven', guanil 'se dice del ganado que vive en estado salvaje', Tetir, tabaiba 'nombre genérico de varias especies de plantas de la familia de la euforbiáceas', amolán 'manteca de leche de cabra', esquén 'corral de piedra para el ordeño (ant.)' (presente también en los topónimos Esquén, Esquencillo, (Lomos de) Lesque, Izque, Tenisca, Izcagua, etc.), guanche 'se dice de los antiguos habitantes de la isla de Tenerife y, por extensión, de los del resto de las Islas Canarias' ${ }^{14}$, mije 'puerta del corral de las cabras, cuando tiene dintel' (míjano 'boca de la acequia'), Adeyahamen, Adeje, Tindaya (Tindayeja), tafor 'primera leche que da la hembra de ciertos animales los primeros días después de parida, calostro', tagasaste 'especie de arbusto leguminoso alto', Orotava, etc.

Aunque no se les ha encontrado un étimo tan incontrovertible como a los anteriores, tradicionalmente también se han clasificado como originarios de la lengua guanche otras muchas palabras absolutamente comunes en el español insular, como los que se citan a continuación:

baifo 'cría de la cabra' ${ }^{15}$, puipano 'se dice de la cabra blanca con manchas canelas o bermejas', tofio 'vasija de barro con pico', taferte 'matacandil, planta herbácea', tabajoste 'vasija de barro con pico', gena 'morral hecho con la piel de una cabra', chagüiguo 'charco que queda en el cauce de los barrancos', tefio 'pequeña oquedad en el terreno en que anidan las pardelas', pírgano 'tallo de la hoja de la palmera', manajaisa 'se dice de la oveja negra con una mancha blanca en la cabeza', tabajoste 'vasija de barro con pico'; Chilegua 'nombre de un lugar de Fuerteventura', tamasma 'aguzanieves, pájaro de unos 8 centímetros', agonane 'planta herbácea de la familia de las crucíferas', bejeque 'nombre genérico de casi todas las especies de plantas que los científicos denominan Sempervivum o Aeonium', Canarias 'nombre del archipiélago', Chipude 'nombre de un pueblo de La Gomera', Garachico 'nombre de un pueblo de Tenerife', guásimo (guársamo) 'concavidad que se hacía al pie del tronco de un árbol para recoger el agua que destilaban sus hojas', Tamateje 'nombre de una montaña en Fuerteventura', mocán 'árbol de la familia de las teáceas', tajaraste 'pandero

${ }^{13}$ De ser cierta esta etimología sugerida por Abraham Louft, la variante más antigua de esta palabra canaria de procedencia bereber debió de ser, no perenquén, que es la más generalizada hoy en el archipiélago, sino perinquén, que es la que se usa en las hablas insulares más arcaizantes, como la de Fuerteventura, y la que recoge Viera (1987: s. v.).

14 Tanto desde el punto de vista fonético como desde el punto de vista semántico e histórico, resulta absolutamente inverosímil la hipótesis de que la voz canaria guanche proceda de un supuesto deverbal del francés antiguo guenchir 'balancearse', como sostienen M. Trapero y E. Llamas Pombo (1998: 99-196). Una crítica filológica de esta hipótesis románica del canarismo guanche puede verse en Morera (2007: s. v. guanche).

15 Tampoco se puede descartar la posibilidad de que nos encontremos ante una forma hispánica, procedente del canarismo gaifo, variante formal de galpo (síncopa antigua de gallopito) 'pollo débil, enfermizo y de pocas medras', por extensión semántica. Para la etimología de galpo, vid. J. Corominas y J. A. Pascual (1980-1991, s. v. galpito). 
rústico', 'canto y baile populares que se ejecuta al son de un tambor', amagante (tamagante) 'arbusto de la familia de los cistus', asaigo (tasaigo) 'arbusto de la familia de las rubiáceas', Tamargada 'nombre de un lugar de La Gomera', Ugán 'nombre de un lugar de Fuerteventura', Uga 'nombre de una localidad de Lanzarote', Mogán 'nombre de una localidad de Gran Canaria', Chinamada 'nombre de un lugar de Tenerife', Taganana 'nombre de un lugar de Tenerife', Teguise 'nombre de un lugar de Lanzarote', Ajódar 'nombre de un lugar de Gran Canaria', Guatisa 'nombre de un lugar de Lanzarote', Tamasite 'nombre de una montaña de Fuerteventura', Tinajo 'nombre de un pueblo de Lanzarote', Tuineje 'nombre de un pueblo de Fuerteventura', taro 'construcción rural en forma de torre circular', cairo (jairo) 'se dice de la cabra doméstica', cairano (cairamo) 'morral hecho de piel de cabra'16, cairero 'pastor de cabras', etc.

Tanto unas como otras constituyen lo que los estudiosos suelen denominar guanchismos, es decir, palabras o expresiones de procedencia guanche total y radicalmente integradas en la lengua española que se habla en Canarias ${ }^{17}$.

Desde el punto de vista de su mayor o menor extensión de uso, estos guanchismos pueden clasificarse en dos grupos distintos: a) Guanchismos que funcionan como denominaciones generales de las cosas que designan: v. gr., gofio, tabaiba, tajinaste, perinquén, etc. Por tratarse del nombre oficial de dichas realidades, carecen de connotaciones peyorativas, por lo que suelen usarse de forma natural en la lengua escrita. De ahí la vitalidad que presentan en el habla insular; y b) Guanchismos que funcionan como meros tecnicismos locales de las cosas que designan: v. gr., baifo, beletén, tefío, goro, time, tenique, amolán, gena, tofio, tafeña, guanil, etc. Por tratarse de denominaciones locales con correlato en la norma estándar del idioma, muchas de ellas se encuentran cargadas de connotaciones peyorativas, lo que las ha mantenido alejadas de la lengua escrita. De ahí los problemas de legitimidad que las mismas han presentado a lo largo de la historia del español insular. En la actualidad, en que la modernidad ha alterado de forma radical las formas de vida ganaderas, ámbito referencial al que pertenece la mayor parte de las voces canarias de sustrato $^{18}$,

\footnotetext{
16 También podría tratarse de la palabra española cabra, con vocalización de la consonante labial. De ser así, tendríamos que jaira no sería otra cosa que una variante de expresión de caira, con fricatización de la velar inicial, y cairano (variante de expresión cairamo) y cairero 'pastor de cabras', meros derivados de dicha voz, en -ano el primero y en -ero el segundo. Ya nos había advertido Alvar (1993: 174) que las formas cairano y hairamo "no se pueden separar de la jaira 'cabra doméstica', de cuya piel se hacen estas bolsas o mochilas."

17 Hasta tal punto es así, que muchos de ellos aparecen recogidos en el diccionario de la RAE, generalmente con la indicación de voz prehispánica, voz guanche o voz autóctona. Es lo que sucede en el caso de la formas baifo, gofio y tajaraste, respectivamente. En otros casos, se proporciona la etimología exacta de la voz: v. gr., tenique, de la que se indica que procede "del berb. tenik o čenik" (RAE, 2001: s. v.).

${ }^{18}$ El primero en plantearse el problema de la clasificación referencial del material que nos ocupa fue S. Berthelot (1978: 118-125), que lo dividió en los once grupos siguientes: calificación
} 
los guanchismos que nos ocupan se encuentran al borde de su desaparición. Así, tenemos que formas como time, arife, tefío, goro, guirre y chagüiguo, por ejemplo, casi se reducen hoy al ámbito de la toponimia (El Time, Tefía, El Goro, Barranco de los Chigüiguos, Tenerife, Terife, etc.) y al de las expresiones hechas (estar alguien más flaco que un guirre 'estar muy flaco', estar más enguruñado que un guirre 'estar muy encogido', tener algo como un goro 'tenerlo muy sucio'), que son los reductos últimos de las palabras que nos dicen adiós. Es lo que explica el carácter exótico o pintoresco que presentan muchos de estos empréstitos guanches en el habla canaria actual. El problema viene desde atrás. Como escribe J. A. Álvarez Rixo (1991: 32-22), desde el siglo XIX, "algunos nombres de los indígenas se van perdiendo, sustituyéndoles otros castellanos por distintas casualidades, siendo lástima que, un par de siglos antes, no hubiese ocurrido a otro hacer la colección de ellos. Por ejemplo, al nombre de Acentejo sustituyó La Matanza; al de Agey, pueblo de la isla de Lanzarote, San Bartolomé, por haberse edificado allí una ermita a la advocación de dicho santo; al desierto terreno en el Puerto del Arrecife, de la misma isla, nombrado Yabago, el de Calle Nueva, por construirse una calle en aquel paraje el año 1805, hasta cuya fecha retenía el primero, etc. En las demás islas ha sucedido lo mismo"19. Y ello independientemente de que muchos topónimos guanches fueron traducidos al español desde el principio de la conquista. Es lo que sucedió con el nombre Aguere con que designaban los guanches a la que sería primera capital de la isla de Tenerife, convertido por los castellanos en La Laguna.

En todo caso, el hecho de que se trate de voces que han entrado en la lengua de acogida por tradición oral las ha expuesto a dos tipos de transformaciones distintas, aunque complementarias.

de la divinidad, nombres que tienen relación con la religión, títulos y calificaciones de rango y de casta, distinción de sexo y de parentesco, designaciones hidrográficas, armas, trajes y utensilios, comestibles, animales, vegetales y miscelánea. Millares Torres (1974-1980: 300-332) establecerá una clasificación muy similar. Más prolija aún es la clasificación de Wölfel (1996), que ordena el material en diecinueve clases distintas: personas, familia; cuerpo humano y sus atributos; atributos y estados espirituales; cantidad, pluralidad y unidad; nombres de colores; religión; Estado; períodos de tiempo, fiestas; animales domésticos y crías de ganados; plantas cultivables y labranza; comidas y bebidas; indumentaria; enseres de la casa; habitáculos y construcciones; animales en estado salvaje; plantas silvestres; naturaleza y paisaje; nombres de las islas y de sus habitantes; y numerales. Posteriormente, Almeida y Díaz Alayón (1988: 156-159) hablan de los cinco tipos siguientes: fitónimos, ganadería, alfarería, alimentación y miscelánea. Vid. también Morera (1991b: 23-25) y Morera (1993: 20-21).

${ }^{19}$ Razón tienen Almeida y Díaz Alayón (1988: 160) cuando hablan de tres tipos de guanchismos desde el punto de vista de su vitalidad: a) Guanchismos de gran arraigo, como gofio, tabai$b a$, perenquén, baifo, tajinaste, goro y belete; b) Guanchismos de progresivo debilitamiento, como carabuco, eres, gainás, gambuesa, gánigo y tabona; y c) Guanchismos ya desaparecidos del vocabulario activo, como amolán, tamarco, majo, tafuriaste, taferte y tesegue. 
De un lado, experimentaron una primera transformación más o menos general para adaptarse a los patrones fónicos y gramaticales de dicha lengua, que son, como es natural, radicalmente distintos de los propios de las lenguas bereberes $^{20}$. Es lo que podríamos llamar fase de adaptación del préstamo (Morera, 2005a: 19). Así, los citados préstamos Tamarssit, Tazart, walden, Tagant y Chimich adoptaron las formas Tamaraceite, Tasarte, beletén, Tacande y Chimiche, respectivamente, convirtiendo en explosivas algunas de sus consonantes implosivas mediante la adición de nuevas vocales, para adaptarse así a las tendencias silábicas más habituales de la lengua española, que es la sílaba abierta; las formas tabrait, Tamarssit, Amnay e inke devinieron Teberite, Tamareceite, Amanay y Tenique, escindiendo en dos sílabas distintas los grupos consonánticos /br/, /rs/, /mn/ y /nk/, también mediante adición vocálica; las formas agrur, tawwunt, tirufin y tebebi pasaron a goro, tabona, tafeña y tabaiba, para adaptarse a los patrones morfológicos de la lengua española; y las formas Ti-nirifi, per-n-inken y wa-n-il se convirtieron en Tenerife, perinquén y guanil, perdiendo su estructura sintagmática nombre-n-nombre, absolutamente ajena a la lengua española (Hamouma, 1976: 68); como también perdieron su condición morfológica las marcas de masculino y femenino bereberes $a$ - y $t a$ - (y sus respectivos plurales $i$ - y $t i-$ ) (Hamouma, 1976: 39-46) y la marca de plural y colectivo - $e(a, i) n$ (Hamouma, 1976: 44-46) ${ }^{21}$. En este último aspecto, nos encontramos con que determinados guanchismos no son otra cosa que variantes gramaticales de una misma forma originaria. Ese parece ser el caso de las formas amagante 'arbusto de la familia de los cistus' y asaigo 'arbusto de la familia de las rubiáceas', procedentes de sus correspondientes masculinos guanches, que presentan también las formas tamagante y tasaigo, adaptacion de sus

${ }^{20}$ Como es natural, el problema de la recepción de las palabras guanches por parte de los hablantes españoles ha sido muy debatido en la lingüística canaria. El primer autor en considerar el asunto de forma detenida fue J. D. Wölfel (1996). Para Juan Álvarez Delgado (1981: 15-16), "las formas guanches de uso actual se han eufonizado en su mayoría para adaptarse a la base articulatoria del español; y por ello han sufrido al principio y al final adición o pérdida de fonemas; y variaciones de timbre o punto de articulación; y hasta en su interior han sido parcialmente alteradas". Posteriormente, yo mismo he dedicado a este asunto mis ensayos Morera (1991a: 41-65) y Morera (2005b: 117-153). Más recientemente, Ahmed Sabir (2001: 50) nos ha vuelto a recordar que "por loabilísima que es la labor de los primeros investigadores canariólogos quienes nos legaron la materia del patrimonio lingüístico y cultural aborigen canario hoy disponible, la visión objetiva de los hechos nos obliga a reconocer que habida cuenta de sus idiomas nacionales netamente diferentes del canario aborigen, estos no se hallaban necesariamente preparados para asegurar una reproducción fiel de aquellos extraños vocablos aborígenes isleños. De hecho, ni la estructura general, ni la pronunciación, ni la morfología de sus respectivas lenguas (español, alemán, francés, inglés, portugués, italiano...) tenían por qué corresponder exactamente a las del canario aborigen; por lo que faltaba el adecuado oído para captar fielmente tan extrañas voces a menudo oídas por vez primera, lo mismo que la preparación necesaria de su aparato fonatorio para reproducirlos".

${ }^{21}$ Ya había señalado Glas (2010:202) que "los plurales guanches como los libios terminan en $n$, pero nuestro autor (se refiere a Abreu Galindo) los ha cambiado". 
correspondientes femeninas; el caso de la forma belete 'leche que da la hembra de determinadas especies animales los primeros días después de parida' y esque 'corral de piedra para el ordeño', adaptación de las formas singulares o colectivos correspondientes, que presentan también las variantes beletén y esquén, adaptación de sus correspondientes plurales; o el caso de la forma chagüiguo 'charco en el cauce de los barrancos', adaptación de la forma singular femenina, que presenta también (aunque solo fijada en la toponimia de Fuerteventura: Barranco de los Chigüiguos, Playa de los Chigüiguos, Baja de los Chigüiguos, etc.) la forma chigüiguo, adaptación del femenino plural correspondiente. Por todo ello, hay que decir que las palabras canarias gofio, goro, beletén o tajorase, por ejemplo, no son voces guanches corrompidas, sino voces españolas perfectamente coherentes con los principios fónicos, gramaticales y léxicos de esta lengua. Digamos que las formas guanches originales han servido de material o punto de partida para crear nuevas raíces léxicas dentro de la lengua española. De todo lo cual se deduce que, sin un conocimiento profundo de los sistemas fonológico y gramatical de las dos lenguas en liza, es absolutamente imposible explicar con seriedad el material idiomático que consideramos.

De otro lado, convertidas ya en voces hispanas, estas viejas palabras bereberes siguieron evolucionando formal, gramatical y semánticamente en función de las tendencias propias de cada etapa histórica de nuestra lengua y de las necesidades comunicativas de los hablantes insulares. Es lo que podríamos denominar fase de evolución del préstamo (Morera, 2005a: 120).

En el ámbito formal, estos guanchismos fueron afectados en principio por los cambios fónicos sistemáticos (velarización de la palatal fricativa $/ \int /$, aspiración de /s/ implosiva...) que experimentaron el español general y el español canario después de la conquista y colonización de las islas, al tiempo que sufrieron también alguna que otra transformación esporádica particular (cambios de timbre vocálico, pérdida de determinadas vocales o consonantes, metátesis...), que determinaron en ciertos casos que una misma voz se escindiera en dos o más variantes de expresión distintas. Es lo que puede haber ocurrido en el caso de las formas siguientes: tamasma 'aguzanieves', que presenta también las variantes formales tamaima y tamaisma; perinquén 'salamanquesa', que presenta también las variantes formales perenquén y pracan; tabaraste 'especie de ajo silvestre', que presenta también la variante formal tarabaste; tenique, que presenta también las variantes de expresión tonique y teneque, además de las palatalizadas chínique, chenique, etc.; Tenemijay "nombre de un lugar de Fuerteventura', que presenta las variantes de expresión Teremijay y Trimijoy; Añamás 'nombre de un lugar de Fuerteventura', que presenta también la variante de expresión Ayamás; tofio 'vasija de barro con pico', que presenta también la variante de expresión tojio; tadaigo 'arbusto de la familia de las rubiáceas', que presenta también la variante de expresión tasaigo; time 'borde de un acantila- 
do', que presentan también las variantes de expresión etime y letime, con aglutinación del artículo, por fonética sintáctica; Esque, que presenta también la variante de expresión Lesque, igualmente con aglutinación del artículo.

En el ámbito semántico, algunas de estas voces pasaron a constituir oposición léxica inmediata con palabras españolas de denotación similar. Es el caso de los guanchismos gofio, baifo y puipano, por ejemplo, que pasaron a constituir oposición léxica inmediata con las formas españolas harina, cabrito y berrenda sobre los contrastes semánticos 'harina de granos de cereales tostados'/ 'harina de granos de cereales crudos', 'cría de la cabra desde que deja de mamar hasta que le apuntan los cuernos'/ 'cría de la cabra desde que nace hasta que deja de mamar' y 'se dice de la cabra blanca con manchas canelas o bermejas'/ 'se dice de la cabra blanca con manchas negras', respectivamente. En realidad, lo que decimos afectó a la inmensa mayoría de las voces guanches relativas a la leche, los colores del pelaje de cabras y ovejas ${ }^{22}$, las marcas del ganado ${ }^{23}$, los tipos de ganadería, etc., que, al integrarse en sistemas léxicos distintos, adquirieron nuevos sentidos, imposibles de determinar con seguridad.

Otras desarrollaron acepciones nuevas por contigüidad metonímica, por aplicación metafórica o simplemente por extensión semántica. Así, guirre 'alimoche', por ejemplo, añadió a su sentido originario las acepciones 'persona desmirriada y enfermiza' y 'órgano sexual femenino'; tafeña 'grano de cereales tostado', la acepción 'zurra de azotes'; guanil 'se dice del ganado que vive en estado salvaje', las acepciones 'se dice del ganado de suelta que no tiene marca', 'se dice del ganado de suelta que no tiene dueño', 'se dice de la cabra o de la oveja que ha sido abandonada por su madre', 'se dice del animal pequeño o débil', 'se dice de la persona o cosa pequeña', 'se dice de la persona, animal o cosa con pareja que se ha quedado sin ella' y 'persona desocupada'; goro 'corral de piedra', las acepciones de 'pocilga', 'cueva natural empleada como refugio por los pastores', 'huerto pequeño', 'pequeño corral, generalmente junto a otro mayor, para cerrar baifos' y 'especie de seto redondo para resguardar plantas de jardín o frutales'; tabaiba 'nombre genérico de varias plantas de la familia de las euforbiáceas', la acepción de 'persona torpe y simple'; tenique 'pie-

${ }^{22}$ El primer estudioso en ocuparse con rigor de esta rica parcela del vocabulario canario fue Francisco Navarro Artiles, en su Campo semántico de colores de cabra en Fuerteventura (inédito). Más tarde, José Luis Ramos Saavedra hará lo propio con el vocabulario de colores de ganado en la isla de El Hierro (inédito). Posteriormente, yo mismo, siguiendo la metodología de Navarro Artiles y Ramos Saavedra, que era la metodología de los campos léxicos de la semántica estructural, exploré el asunto en mis Morera (1991c: 117-145) y Morera (1995: 551-568). Por último, al mismo tema que Ramos Saavedra, dedica M. Trapero el capítulo III de su obra Trapero (1999: 69-117).

${ }^{23}$ También fue Francisco Navarro Artiles (1989: 321-345) el primero en estudiar de forma sistemática los nombres de las marcas que emplean los pastores canarios para distinguir las cabras de suelta. Más tarde, Trapero (1999: 79-82) dedica un breve apartado al mismo asunto. 
dra del hogar', la acepción de 'piedra de regulares dimensiones'; gofio 'harina de cebada tostada', la acepción de 'harina de millo, trigo, etc., tostado'; etc. A este mismo capítulo de ampliación de uso, pertenecen también los guanchismos que han desarrollado funciones toponímicas dentro del español: v. gr., el guirre de Pico del Guirre, Vallechuelo del Guirre, Gavias de la Guirra, Majada del Guirre, Lomo de los Guirrecillos; el taro de Rosa del Taro, Hoya del Taro, Gavia del Taro; el tabaiba de Alto de Tabaibita, Charco de la Tabaiba, Caleta de la Tabaiba, Majada Tabaiba, Barranco Tabaibe, Cabezada de Tabaibejo; el perinquén de Degollada de la Perinquena; el mocán de Degollada de Mocán; el esque o esquén de Esquén Alto, Corral del Esquén, Esquén Blanco, Esquén de la Madera, Lomo del Esquenito, Corrales de Lesque, Lesque de Abajo; el majo de Majada del Majo; el goro de El Goro; el gambuesa de Morro de las Gambuesas; etc.

Otras han experimentado desenvolvimientos morfológicos más o menos complejos, como gofio, goro, guirre, baifo, Telde, guanche, tabaiba, Canarias, Chipude, Garachico, mocán, tagasaste, tajorase, tenique, etc., que han desarrollado las variantes morfológicas gofiero 'vendedor de gofio', gofiera 'en el molino, cajón que recoge el gofio mientras se muele el grano', gofiento 'que tiene apariencia o cualidad de gofio', gofión 'relativo al gofio', gofiado 'que parece gofio' y gofiería 'sitio donde se vende gofio' y desgofiar 'hacer polvo algo'; gorón 'pequeño muro circular de piedra', gorona 'ídem' y engorar 'encerrar en ganado en el goro o en el corral'; guirrera 'nido de guirres' y enguirrar 'enguruñarse, encogerse por frío o enfermedad'; baifudo 'se dice del muchacho adolescente' y embaifado 'desganado'; teldense 'natural de Telde'; guanchisnesco 'perteneciente o relativo al pueblo y la cultura guanches', guanchismo 'palabra o expresión canaria de procedencia guanche'; tabaibilla 'lechetrezna' y tabaibal 'terreno cubierto de tabaibas'; canario 'natural de las Islas Canarias', 'especie de pájaro de color amarillo y canto muy melodioso', canarismo 'palabra, locución, giro o modo de hablar propio de los canarios', canarión 'natural de Gran Canaria'; chipudano 'natural de Chipude', chipudero 'ídem'; garachiquense 'natural de Garachico', garachiquero 'ídem'; mocanillo 'pequeño arbusto que produce un fruto negro-rojizo al madurar', mocanero 'mocán', mocanal 'terreno poblado de mocanes'; tagasastero 'especie de arbusto leguminoso alto'; tajorasear 'saltar, brincar como un tajorase'; tenicazo 'golpe dado con un tenique o con cualquier otra cosa', teniquear (tiniquiar) 'apedrear', 'pescar desde tierra lanzando el cordel amarrado a una piedra, para que llegue más lejos', respectivamente.

Otras, por último, han dado como resultado combinaciones sintácticas más o menos complejas de sentidos diversos, como gofio, presente en combinaciones como hacer gofio algo, 'hacerlo añicos', ser más canario que el gofio 'ser muy canario', quien echa gofio a perro ajeno, pierde el gofio y pierde el perro 
'la ayuda a otras personas no trae como consecuencia más que el desagradecimiento'; baifo, presente en combinaciones como saltar como un baifo chico 'dar muchos saltos, de alegría o de dolor, por ejemplo', echar un puño a la baifa 'enamorar los novios', írsele (o escapársele) a uno el baifo 'fallar en alguna cosa, por descuido, olvido o equivocación'; guirre, presente en combinaciones como estar alguien hecho un guirre 'no disfrutar de buena salud'; tofio, presente en combinaciones como lo que no va para la era va para el tofio 'lo que no se aprovecha de una manera se aprovecha de otra'; eres, presente en la parte final del topónimo tinerfeño Pinolere (de Pino del Eres); perinquén, presente en combinaciones como ser más feo que un perinquén 'ser muy feo', estar más negro que un perinquén 'estar muy negro', pegarse alguien como un perinquén 'adherirse fuertemente a una cosa'; guirre, presente en combinaciones como estar más flaco que un guirre, 'estar muy flaco' (Ortega Ojeda y González Aguiar, 2000), etc.

Todos los cambios comentados hasta aquí determinan que la fidelidad que estas palabras guardan a la lengua aborigen sea más bien escasa. Y es que, en realidad, voces como Tenerife, guanil o Tindaya, por ejemplo, no tienen ya identidad lingüística bereber, donde, según dicen algunos estudiosos, habrían significado 'la del calor', 'el que vive libre' y 'las de abajo', sino identidad lingüística hispana, porque sus propiedades fónicas, gramaticales y léxicas no son bereberes, sino españolas. Como señalábamos en nuestro trabajo de 1991 citado más arriba:

la relación entre los guanchismos y sus étimos es meramente tangencial: las palabras aborígenes sirvieron de punto de partida para el desarrollo de nuevos valores semánticos, de términos meramente nomencladores o de acepciones nuevas en palabras españolas, unidades nuevas que ahora dependen exclusivamente de las relaciones de oposición y de contraste existentes en el seno de nuestra lengua y que, por lo tanto, nada deben a las lenguas indígenas (Morera, 1991: 62) 24 $^{24}$

Ya había indicado Saussure de forma general que:

Las palabras de préstamo ya no cuentan como tales préstamos en cuanto se estudian en el seno del sistema, ya no existen más que por su relación y su oposición con las palabras que les están asociadas, con la misma legitimidad que cualquier otro signo autónomo (Saussure, 1973: 69).

En segundo lugar, entre los restos que sobrevivieron a la desaparición de la lengua guanche, encontramos palabras o expresiones como:

amenzay 'régulo, rey' (originariamente, 'primogénito que solía servir de guía y de ejemplo para sus hermanos menores, y que asumía a menudo la respon-

\footnotetext{
${ }^{24}$ El mismo parecer ha sido defendido posteriormente por M. Trapero (1998: 43-44).
} 
sabilidad del padre en caso de ausencia o muerte de este') (Sabir), akchir amenzay 'hijo del mencey', wi-n-tagut 'el de la nube' (Sabir), Аcaymu 'antropónimo' (de acaymu 'negro') (Sabir), tamagwat 'adolescente, virgen' (Louft), wa-n-ismer 'agosto' (originariamente, 'el que está bajo el sol') (Louft), wa-n-Artamy 'el del Artamy' (Louft), ilmoggaren 'adoratorio' (Sabir), tagrurt 'asamblea' (Sabir), abrok 'vestido de lana blanca' (Wölfel),

que, tras un complejo proceso de adaptación formal y gramatical al oído de los eruditos, se convirtieron en las palabras canarias mencey 'entre los antiguos habitantes de Tenerife, rey', achimencey 'hijo del mencey', Bentagoche, Acaymo, maguada (harimaguada) 'doncella que los aborígenes encerraban en ciertas casas religiosas', beñesmer 'época de los meses de julio y agosto', guanarteme 'en Gran Canaria, rey', tagoror 'lugar donde el mencey celebraba juntas y consultas', tamarco 'vestido de piel de cabra', etc.

Aunque no se ha podido dar con su origen exacto, es muy probable que asimismo pertenezcan a este mismo grupo léxico palabras insulares como añepa 'palo largo en forma de lanza que empleaban los antiguos habitantes de la isla de Tenerife', banot 'lanza arrojadiza de tea endurecida al fuego de los aborígenes canarios', faicán 'entre los indígenas grancanarios, sacerdote que seguía en el rango al guanarteme', etc.

También en este caso es legítimo hablar de guanchismos, puesto que se trata de voces perfectamente integradas en los patrones fónicos y gramaticales del español hablado en Canarias. No obstante esto, los mencionados materiales presentan una diferencia radical respecto de los anteriores: mientras que, como vimos más arriba, estos últimos experimentaron un desarrollo fónico, gramatical y semántico más o menos intenso, por su carácter popular, los que nos ocupan apenas han experimentado desarrollos fónicos, gramaticales y léxicos ulteriores, por su carácter culto o artificial, por tratarse de términos de los eruditos de la historia, la prehistoria, la arqueología y la etnografía de las Islas Canarias, principalmente. Es decir: mientras que los primeros pasaron sucesivamente por las fases de adaptación y de evolución mencionadas más arriba, los segundos solamente experimentaron la fase de adaptación. Excepciones a esta regla las constituyen las formas mencey y ahoare (de Benahoare, nombre indígena de la isla de La Palma), que han desarrollado los derivados cultos menceyato "cada uno de los nueve reinos en que estaba dividida la isla de Tenerife al tiempo de la conquista', con el incremento sufijal -ato, y auarita 'antiguo habitante de la isla de La Palma', con el incremento sufijal -ita. Solamente en los tiempos modernos, con el auge de los movimientos indigenistas, han experimentado las palabras que nos ocupan cierta expansión en el habla popular. Es lo que ha sucedido con antropónimos (o supuestos antropónimos) guanches como Aday, Ayatima, Nauzet, Doramas, Faina, Acaymo, Idaira, Ayoze, Zebenzuí, Iballa, Dácil, Andamana, Guacimara, Guayarmina, Rayco, Ruymán, Ico, Armiche, 
Tanausú, etc., tan frecuentes actualmente en la onomástica personal ${ }^{25}$ de las islas, en la denominación de edificios, etc. Un caso especial lo constituye el citado nombre común tagoror, instituido recientemente por el ayuntamiento santacrucero para designar los órganos municipales de representación vecinal ${ }^{26}$.

En tercer lugar, destacan en el ámbito de los restos lingüísticos guanches palabras y expresiones como:

tomzen 'cebada' (Sabir), yerden 'trigo' (Sabir), ahra 'oveja' (Sabir), yelf 'cerdo' (Sabir), aggad (agha) 'cabra' (Sabir), tamettut (chamet) 'mujer' (Sabir), tahart-emen 'higo dulce' (Louft), aremorchase 'higo verde' (Louft), ahemon 'agua' (Louft), wa-n-ak 'lo que es de todos' (Cubillo), agofai 'leche fresca' (Louft), ah indawen 'leche mecida' (Louft), igam, igam 'basta, basta' (Sabir), tahuyot 'manto' (Sabir), tigot (plural, tigotan) 'el cielo' (Sabir), ta-serken (cha-serken) 'algo contra la debilidad' (Cubillo) ${ }^{27}$, etc.,

que los cronistas de la conquista adaptaron a la fonética insular, transcribiendo, con mayor o menor acierto, como tamozén 'ídem', irichen 'ídem', ara 'ídem', ilfe 'ídem', aha (o axa) 'ídem', chamato 'ídem', tehaunemen 'ídem', arehormase 'ídem', ahemón 'ídem', guañac 'república', ahof 'ídem', adago 'leche de cabra', gama, gama ídem', tigot (o tigotán) 'ídem', tahuya 'falda de pieles pintadas', chacerquén 'miel de mocanes', etc.

Aunque sus étimos no se han podido identificar con total claridad, también parecen pertenecer a este capítulo del material que clasificamos las palabras y las combinaciones que siguen, no solamente porque lo indican los cronistas que las recogieron, sino también por su misma estructura material:

tamasaque 'bordón' (Abreu) ${ }^{28}$, jubaque 'oveja gorda y de mucha grasa' (Abreu), alzanxiquian abcanahac xerac 'lugar del nacimiento del hijo del grande' (Espinosa), Agoñe Yacoran Yñatzahaña 'juro por el hueso de aquel día en que te hiciste grande' (Espinosa), aridaman 'cabra' (Abreu), tahatan 'oveja' (Abreu), taqueazen 'cerdos' (Abreu), tamazanona 'fritura de carne

25 Antiguamente, cuando lo guanche carecía de prestigio, se huía de tales denominaciones, como señala G. Glas (2010: 117-118): "las grandes familias de estas islas se sentirían altamente ofendidas si alguien les dijera que son descendientes de los moros, o incluso de los antiguos habitantes de estas islas (...). La gente bien educada y todos los españoles se sienten orgullosos de descender de los godos".

26 Así explica el ayuntamiento de Santa Cruz la denominación en su página web: "En Santa Cruz a estos órganos los hemos denominado Tagoror, haciendo un homenaje a nuestros ancestros. Para ellos era la asamblea donde se reunían los aborígenes para dilucidar sobre los problemas y conflictos bajo la autoridad del mencey.".

27 Para Sabir (2001: 157), podría tratarse más bien de un hipotético femenino del bereber aserka 'jugo viscoso y más bien oscuro de cualquier materia líquida que se deposita en el fondo de un recipiente'.

${ }^{28}$ Nos referimos a Fray Juan de Abreu Galindo (1977). 
con sebo y manteca' (Abreu), azamotan 'cebada' (Abreu), tebexcorade 'agua buena' (Abreu), aguayan 'perro' (Abreu), teguevite 'cabra' (Abreu), Y iguida y iguan Idafe 'dice que caerá Idafe' (Abreu), Que guerte yguan taro 'dale lo que traes y no caerá' (Abreu), vacaguaré 'quiero morir' (Abreu), adijirja 'chorro de agua' (Abreu), Ayatimasquaya 'bajo los riscos' (Abreu), anarfeque 'incienso' (Abreu), achicuca 'hijo' (compuesto de la forma akchir 'niño') (Abreu), zucasa 'hija' (Abreu), ahoren 'cebada tostada y molida' (Abreu), tamo 'cebada' (Abreu), cancha 'perro pequeño' (Abreu), coran 'hombre' (Abreu), Guayaxiraxi 'el que tiene el mundo, dios' (Abreu), Chaxiraxi 'la que carga al que tiene el mundo, la virgen' (Abreu), Tamogantacorán 'la casa de Dios' (Abreu), agonec 'yo juro', Hehiles huhaques abentourames 'escápate pronto, pues corre tras de ti' (Abreu), etc.

Nos encontramos, como es obvio, ante un proceso de transmisión radicalmente distinto del visto en los dos casos anteriores: ahora el cronista no pretende adaptar estas voces o frases indígenas a la lengua española, sino reproducirlas de la forma más fielmente posible, aunque, como es natural, esto sea una quimera, tanto desde el punto de vista fonético como desde el punto de vista gramatical. Desde el punto de vista fonético, porque, como es evidente, el adaptador solamente podía oír lo que le permitía su sistema fonológico español, que, además, transcribía a un sistema ortográfico adaptado a las necesidades de los fonemas de esta lengua, no a los de la lengua bereber ${ }^{29}$. ¿Cómo transcribir las, al parecer, tan características consonantes glotales y geminadas del guanche al español, si esta lengua carece de ellas, como carece, consecuentemente, de letras para representarlas $?^{30}$ Desde el punto de vista gramatical, porque, como es evidente, el transmisor español no estaba preparado para entender las sutilezas categoriales, morfológicas y sintácticas del bereber, tan distintas de las suyas propias. Así se explica que, en ciertos casos, se llegara incluso a mezclar en una misma palabra formas guanches y formas españolas, como denuncia Álvarez Rixo en el caso de la frase recogida por Sosa ¿Hau eres tú Utindana? (Sosa, 1994: 165), donde se mezclan las formas españolas tú y eres con las supuestas formas guanches Hau y Utindana (Álvarez Rixo, 1991: 50-51); lo mismo parece haber sucedido en el caso del antropónimo Guayrinfanta, mezcla de la supuesta forma guanche guayre y la forma española infanta, como señaló Berhelot ${ }^{31}$. No se

\footnotetext{
${ }^{29}$ Ya había señalado Berthelot (1978: 145) que todas estas palabras "no han sido escritas con su verdadera ortografía. Desfiguradas por una pronunciación viciosa, no sabríamos en la actualidad darles su verdadera cadencia".

${ }^{30}$ En una ámbito lingüístico como el canario, donde nunca se ha distinguido entre $/ \mathrm{s} / \mathrm{y} / \mathrm{z} /$, no dejan de llamar la atención las zetas y la ces de guanchismos como Yaiza, Acentejo, Tamaraceite, mencey, Tazacorte, Azuaje... ¿Existía sibilante interdental en guanche? No lo parece. ¿Se trata de un uso arbitrario de la grafía $z(c)$ ? No lo sabemos. ¿Se trata de un intento del escribano por reflejar alguna particularidad (sonoridad, por ejemplo) de la sibilante originaria? Podría ser.

31 "Ciertos nombres citados por los historiadores nos parecen de construcción española; así, por ejemplo, al llamar guayrinfanta a una princesa de la isla de La Palma, los conquistadores compusieron evidentemente este nombre de la palabra guayre, que servía para designar en Cana-
} 
trata ahora de palabras del español de Canarias, puesto que ni han sido adaptadas totalmente a los patrones fónicos y gramaticales del habla insular ni las han utilizado nunca ni el pueblo ni los eruditos de las islas. Se trata más bien de meras glosas o citas de formas guanches, como ponen de manifiesto las mismas fórmulas que usan los cronistas para presentarlas:

Peleaban con grandes bastones de palo —dice Abreu (1977: 60-61)—, que llamaban $^{32}$ tezezes. A los valientes llamaban altihay. Las mujeres traían tamarcos de cueros de cabras, y encima pellicos o ropillas de cuero de carnero, y los mesmos bonetes pelosos del mesmo cuero. Servíanse de cuchillos de lajas de pedernal, que llamaban tafiagues. Al cuero llamaban argüí, y al ganado salvaje, guanil.

Según el padre Alonso de Espinosa (1980: 33),

los naturales guanches viejos dicen que tienen noticia de inmemoriable tiempo, que vinieron a esta isla sesenta personas, más no saben de dónde, y se juntaron y hicieron su habitación junto a Icod, que es un lugar de esta isla, y el lugar de su morada llaman en su lengua Alzanxiquian abcanahac xerac, que quiere decir: 'Lugar del ayuntamiento del hijo del grande'.

De ahí que se pueda afirmar que se trata de las palabras guanches más puras que se conservan. El problema, sin embargo, es que, a las modificaciones que experimentaron estas voces exóticas al pasar por el filtro lingüístico de los cronistas que las transcribieron al español, hay que sumar las deformaciones que las mismas sufrieron en su transmisión de unos copistas a otros a lo largo del tiempo $^{33}$. Es el caso de la forma hara 'oveja', transcrita también como haña; tafrique 'cuchillo', transcrita también como tabiaques ; guatiboa 'convite', transcrita también como guatativoa, guatibao y guatativaa; Benahoare, transcrita también como Beahoare y Benahoave; gánigo 'vasija con pico', transcrita también como guánigo y guanigo ${ }^{34}$; amolán 'manteca de leche de cabra', transcrita

ria a un príncipe o a un personaje de elevado rango, y de la palabra infanta (en castellano). Es sorprendente que Galindo y Viera hayan aceptado sin examen esta expresión de guayrinfanta (la hija del guaire o la infanta) como perteneciente exclusivamente al antiguo lenguaje, sin apercibirse de su doble origen" (Berthelot, 1978: 144).

${ }^{32}$ La negrita es nuestra.

33 Al margen de este problema quedan, como es evidente, las variantes diatópicas existentes en la misma lengua guanche, propiciadas por el hecho insular. Como señala Viera (1982: 55), “QQuién se admirará de que nuestros primitivos isleños, habiendo vivido sin comunicación ni comercio durante una larguísima serie de años, corrompiesen su lenguaje hasta darle una diferencia sensible?".

${ }^{34}$ Según Álvarez Rixo (1991: 28), “en Gran Canaria se decía gánigo; en Lanzarote y Fuerteventura, guanigo; en Tenerife guánigo. Y la primera ha prevalecido en toda la provincia". Podría ser, pero si no se aportan más datos, parece más lógico pensar que se trata de transcripciones distintas de la misma voz. 
también como aculan; Arure 'nombre de un lugar de La Gomera', transcrita también como Aruce; Encherada 'nombre de un lugar de La Gomera', transcrita también como Encherda; Tesejerague 'nombre de un lugar de Fuerteventura', transcrita también como Tezagerague, Tesagerague, Tesarague y Setegerage; Tibitafe 'nombre de una montaña de El Hierro', transcrita también como Tifirafe; Tiscamanita 'nombre de un lugar de Fuerteventura', transcrita también como Tisquemanita; etc. ${ }^{35}$ Un caso muy llamativo de estas deformaciones nos la proporciona la forma majorera esquén, convertida en efequén por los copistas del texto de Abreu (que es quien la recoge por primera vez), que leyeron la ese larga de la escritura original como efe, como señaló Francisco Navarro Artiles (1981: s. v. efequén). Las raíces que esta deturpación ha echado en la erudición guanchinesca canaria han sido tan profundas, que incluso un estudioso tan avisado como Alejandro Cioranescu llega a recriminar a W. Vycichl que trabajara en sus estudios etimológicos con la variante esequén, porque, según él creía, se trataba de "un error de lectura" de la forma efequén (Abreu, 1977: 56). Igualmente, muchos de los estudiosos del pasado prehispánico de las islas siguen hablando hoy de los efequenes ('adoratorios') de los aborígenes de Fuerteventura. Pero no hay ni ha habido efequenes en Fuerteventura, sino esquenes, como pone de manifiesto la toponimia de la isla, único ámbito en que hoy se conserva esta voz.

Obviamente, fuera del grupo de los supérstites guanches quedan palabras insulares como:

arrorró 'nana, canción de cuna', bubango 'especie de calabaza pequeña', tabobo 'abubilla', abubiar 'carabritear', chayota 'especie de verdura', fajana 'terreno llano al pie de laderas o escarpes, formado por materiales desprendidos', engodo 'cebo que se echa al agua para atraer el pescado al lugar en que se quiere pescar', alcaidón 'alcaudón', chuchanga 'caracol de tierra', chivato 'chivo pequeño', tarajal 'especie de arbusto', támara 'fruto de la palmera', furnia 'cueva, gruta', gasia 'determinada especie de planta', güero 'se dice del huevo que no empolla', el güiro de la expresión coger los güiros a alguien, 'calarle las intenciones', magua 'pena, desconsuelo', maúro 'hombre del campo', miñoca 'lombriz de tierra', mondiza 'alimañas', pambufo 'gordinflón', ruma 'montón de cosas', sato 'se dice del perro pequeño muy ladrador', sorimba 'atronado, aturdido', taifa 'tanda de trabajadores, bailadores, etc.', til 'árbol de la familia de los laureles', chafariz 'fuente', majalulo 'camello joven', guelfo 'cría del camello mientras mama', barbuzano 'árbol de la familia de las lauráceas', berol 'nombre que se da a distintas especies de

35 Uno de los máximos deturpadores del material idiomático que nos ocupa fue Antonio de Viana (1604), como denunció Berthelot (1978: 117). Se trata de un hecho de una importante capital, por cuanto el poema de Viana han sido considerado fuente privilegiada para el conocimiento de la época prehispánica insular. De ella beben todos los escritores canarios que han hecho literatura de tema guanche. De ahí la denominación de vianistas con que se conoce a estos escritores en las letras insulares. 
plantas crasuláceas', chaboco 'cavidad natural o artificial abierta en la lava, para plantar árboles en la arena soterrada', etc.,

que, aunque han sido clasificados por algunos eruditos como guanches, no son otra cosa, como han advertido ya oportunamente los estudiosos del habla canaria más avisados ${ }^{36}$, que las formas románicas

esp. arrorró, deriv. de ro-ro 'voz que se usa para arrullar a los niños'; port. bogango 'especie de calabacita'; esp. abobo 'abubilla', con sílaba inicial ta-, procedente del determinante bereber $t a-$, por analogía con los guanchismos que la tienen; port. apupar 'perseguir con apupos'; esp. choyota 'fruta de la chayotera', del nahua chayutli 'ídem'; port. fajá 'tierra baja y llana'; port. engodo 'cebo para pescar'; esp. alcaudón; esp. chuchar, con sufijo -ango; esp. chivato; esp. taraje 'ídem', esp. támara 'fruto de la palmera'; port. furna 'cueva, caverna'; esp. acacia; esp. huero 'vano, vacío y sin sustancia'; esp. am. coger los güiros a alguien 'calarle las intenciones'; port. magoa 'pena'; esp. maduro 'que está en sazón'; port. minhoca 'lombriz de tierra'; port. mondiça 'inmundicia'; port. pantufo 'hombre gordo y panzudo'; port. ruma 'montón de cosas'; gallego y asturiano xato 'ternero pequeño'; port. sorumbático 'sombrío, triste'; esp. taifa 'bandada de gente', 'secta'; port. til 'especie de laurel'; chamariz 'construcción de albañilería con varias bocas, por donde corre agua potable' y esp. belfo 'dícese del que tiene más grueso el labio inferior, como suelen tenerlo los caballos', y el ár. sahariano majlul 'camello de uno a cuatro años', port. barbuzano 'ídem', port. chabouco 'foso para los cimientos de una construcción' y port. berol 'pepino de mar', con o sin evolución semántica o formal.

Tampoco son propiamente guanches las voces canarias tasufra 'odre o zurrón' (del bereber tasufre 'odre de piel de cabra para llevar provisiones, etc.'), téfana 'callo de la rodilla de las patas traseras del camello' (del bereber ttefne 'callosidad de los muslos del camello'), tabique 'suero del queso' (del bereber tabikh 'suero de la leche') etc., pues, aunque tienen su origen en lenguas bereberes, no fueron en realidad traídas al archipiélago por los guanches, sino por los esclavos moriscos (bereberes en buena medida) que capturaron los castellanos en los siglos XV y XVI en el norte de África ${ }^{37}$. Es decir, que no se trata de voces de sustrato, sino de voces de adstrato, como advirtió Alvar oportunamente (Alvar, 1993: 254-255).

Como también ha sido señalado por los dialectólogos canarios, tampoco pertenecen al capítulo de los guanchismos los canarismos tebefe 'suero del que-

${ }^{36}$ Uno de los primeros en advertir que muchas de las palabras clasificadas como guanchismos no eran otra cosa que palabras románicas o árabes fue J. A. Álvarez Rixo (1991). Vid. también G. Rohlfs (1954: 83-89).

37 "Con la piratería de África —señala Álvarez Rixo (1991: 101)— se trajeron muchos cautivos, estos también introdujeron algunos de sus vocablos". Vid. también al respecto Morera (2009: 125-163). 
so' y arrife (arrifal, arrifafe) 'terreno baldío, erial', que llegaron al español de Canarias, no a través del guanche, ni a través de otras lenguas bereberes, sino a través de la lengua española y la lengua portuguesa, que las habían adoptado de la lengua de los almorávides que se asentaron en la península ibérica con la dominación árabe, entre los siglos VIII y XV (Navarro Artiles, 1990: 345-346; Morera, 2007).

Exactamente lo mismo sucede con las formas bereberes azarug 'libertad', elhend 'acero', tatanut 'aguja grande', eihed 'asno', aruku 'albarda', abawbaw 'almendra con cáscara', taferet 'arroz', essuker 'azúcar', etc., que encontramos en determinados diccionarios supuestamente guanches (como el de Hupalupa (1980), por ejemplo), que no son otra cosa que palabras tomadas recientemente de las lenguas bereberes del norte de África por los apasionados del pasado canario preeuropeo, como denunció Francisco Navarro Artiles (1981) en su citado Teberite.

¿Se pueden reconstruir con estos restos idiomáticos el sistema fonológico con que se daba forma material a las palabras de la lengua guanche, el inventario de sus raíces descriptivas y mostrativas, los patrones categoriales que daban forma existencial a sus palabras primitivas, los procedimientos morfológicos que presidían la formación de sus palabras derivadas y los procedimientos sintácticos que permitían crear sus palabras compuestas, sintagmas y oraciones? Evidentemente, no. Ya nos advierte L. Hjelmslev (1976: 77) que "debemos renunciar a la ilusión de creer que podríamos reconstruir el sistema exacto de las categorías de un estado de lengua prehistórico", pues "reconstruir significaciones, y, con mayor razón, reconstruir un sistema gramatical, son cosas imposibles". Y ¿por qué no podemos reconstruir el guanche con los escasos rastros que dejó esta lengua en el español canario?

En primer lugar, con estas palabras y frases no podemos reconstruir el sistema fonológico y las reglas combinatorias de los fonemas del guanche simplemente porque los particulares aspectos fonológicos de esas palabras se perdieron totalmente, como es natural, en su adaptación al español (Hjelmslev, 1976: $81)^{38}$. Así, a juzgar por lo que ocurre con sus hermanas del norte de África, es muy probable que la lengua guanche dispusiera de consonantes enteramente ajenas al sistema fonológico de la lengua española, como uvulares, faríngeas, glotales, labializadas y enfáticas, un sistema vocálico de tres unidades, y no cinco como el de nuestra lengua, etc. (Hamouma, 1976). Y nada de eso se conservó ni podía conservarse al traducir las palabras de la vieja población de las islas al idioma de la nueva gente. Esta transformación debió de afectar también de forma considerable a los grupos consonánticos, tan frecuentes en las lenguas bereberes y tan raros en la lengua española.

En segundo lugar, resulta absolutamente imposible reconstruir con estos jirones idiomáticos el inventario de raíces descriptivas y mostrativas que servían 
de base a las palabras de la lengua guanche, en primer lugar, porque el número de raíces que quedaron en ellos (v. gr., GR 'unir, cerrar' (goro, tagoror, gorona), NK 'hogar' (tenique), GN 'dormir' (Tamogante, Mogán), GHRS 'degollar, sacrificar' (tajorase), DRM 'sonreír' (Doramas), BR 'herir, cortar' (teberite), SK 'construir, edificar, levantar un muro' (esquén, Lesque, Escanfraga, Esquinzo, Izque, Tenisca) $R F$ 'tostar, asar, quemar' (arife, Tenerife, Terife, Arafo), LD 'mamar' (beletén), GM 'meter' (gamame), LML 'mecer' (amolán), $R$ 'parir' (Tara), $M N$ 'ver' (Amanay)...), $F$ 'abrigo' (tefio, Tefía) es enormemente reducido y, en segundo lugar, porque muchas de las raíces conservadas se encuentran tan deformadas o fosilizadas en su versión española, que resulta absolutamente imposible identificarlas con un mínimo de garantía científica. Obviamente, con un número tan reducido de raíces léxicas, desgajados además de sus familias de palabras propias, es absolutamente imposible echar a andar una lengua natural ${ }^{39}$.

En tercer lugar, con estos restos no se puede reconstruir el sistema de categorías gramaticales de la lengua guanche porque prácticamente lo único que se conserva de ellas son sustantivos, algún que otro adjetivo, algún adverbio, alguna preposición y poco más, y estos, como es natural, adaptados a los patrones nominales de la lengua española. La consecuencia de ello es que no sabemos cómo eran realmente las categorías de la lengua guanche, y, sin ellas, como es evidente, no se puede dar forma existencial a las raíces, que es la base de las palabras derivadas, las palabras compuestas, los sintagmas y las oraciones.

En cuarto lugar, tampoco podemos reconstruir con los restos que estudiamos el sistema morfológico que servía de base a las palabras derivadas de la lengua guanche porque el número de morfemas originarios que se conserva en estas palabras es exiguo y porque los que se han conservado resultan de muy difícil identificación, por la erosión que sufrieron las palabras que los portaban en su adaptación a la lengua española ${ }^{40}$. No sabemos con seguridad cuáles eran

\footnotetext{
${ }^{38}$ En relación con la pronunciación guanche, solo se conserva la afirmación de Abreu de que hablaban "hiriendo con la lengua en el paladar, como suelen hablar los que no tienen lengua libre, a quien llaman tartamudos. Y en su lenguaje comienzan muchos nombres de cosas ton $t$, los cuales pronuncian con la media lengua" (Abreu, 1977: 34). ¿Se puede deducir de esta observación de nuestro fraile franciscano que la /t/ guanche era retrofleja?

${ }^{39}$ Como se ha dicho siempre, por su diversidad, son los topónimos de procedencia guanche (más que los nombres comunes) el material que más información proporciona sobre las raíces y la estructura gramatical de la lengua guanche.

40 Ya había señalado Álvarez Rixo (1991: 52) que "carecemos de las declinaciones y los verbos de la lengua canaria, que mucho debiera ilustrarnos", aunque albergaba la esperanza de que "tal vez en algún antiguo Ms. se haya tenido la curiosidad de conservar algunos trozos de esta esencialísima parte del idioma”. También S. Berthelot (1978: 141) había señalado que no podía emprender un estudio profundo del guanche porque "no encontraba todos los elementos necesarios en los pocos datos que hasta nosotros han llegado" y que "algunas frases incorrectas citadas por autores que las escribieron sin comprenderlas, las versiones tradicionales con las que acompañaron esta lista de palabras mal articuladas, los fragmentos de los dialectos que nos transmitieron,
} 
los complementos morfológicos de la lengua guanche, y, sin estos elementos, es imposible construir palabras derivadas.

En quinto lugar, no podemos reconstruir con los restos idiomáticos que estudiamos los procedimientos sintácticos de la lengua guanche, de un lado, porque, como dijimos más arriba, no conocemos sus patrones categoriales, que son la base de la sintaxis, y, de otro, porque los elementos que quedaron y que se pueden segmentar con más o menos seguridad son solo sintagmas nominales con complemente determinativo ( $a$-/ ta- y sus plurales $i-/ t i-\mathrm{y} w a-/ t a-$ y sus plurales $w i$ - y $t i-$ ), nombres con complemento cuantitativo $-n$ y sintagmas nominales con complemento del nombre introducido por la partícula $-n-$, y con tan escaso bagaje sintáctico no se puede hablar una lengua natural ${ }^{41}$.

Por último, tampoco podemos reconstruir la lengua guanche con estos exiguos materiales porque, como muchas de estas palabras se recodificaron denotativa y connotativamente al pasar del sistema cultural guanche al sistema cultural español, no sabemos a ciencia cierta qué denotaciones y connotaciones tenían realmente en la lengua de los bereberes insulares. A pesar del esfuerzo hecho por arqueólogos, historiadores, etnógrafos, etc., para determinar el mundo espiritual de la primitiva población insular, nada sabemos con seguridad acerca de sus formas de pensar, de las claves intelectuales que usaban para dar sentido a sus palabras. Con toda seguridad, el buffi de los canarios preeuropeos, por ejemplo, no tenía el mismo sentido que el gofio de los canarios españoles, en primer lugar, porque entraba en una red de relaciones léxicas distintas de las que presenta en español ${ }^{42}$; en segundo lugar, porque la materia prima de que disponían los antiguos canarios para su elaboración (al parecer, solo cebada) no era la misma que la materia prima de que disponen los actuales (cebada, pero

los nombres propios que la historia ha conservado, los que algunas familias llevan aún y las antiguas denominaciones topográficas afectas a ciertas localidades, todo esto no servirá para reconstruir un idioma, después de más de tres siglos de olvido".

${ }^{41}$ Los primeros hablantes maternos del bereber y especialistas en la filología de esta lengua que han intentado determinar con rigor las estructuras morfológicas y sintácticas que subyacen a las palabras que sobrevivieron a la desaparición del guanche han sido los citados Ahmed Sabir (2001) y Abraham Louft (2007). Así, este último (2007: 87-105) clasifica los topónimos canarios de procedencia guanche en los siguientes tipos morfológicos: topónimos con morfema masculino singular a- (Ajuy, Agando, Ajache...), topónimos con morfema masculino plural (Esquén, Iscado...), topónimos con morfema femenino singular ta- (cha-) (Tabagoste, Tarajate, Tajaste...), topónimos con morfema femenino plural ti- (chi-) (Tiritaña, Tisajorey, Tisalaya, Tiagua...), topónimos con preposición direccional ar- (Aragando, Arguamul, Artamache...), topónimos con infijo complemento del nombre - $n$ - (Tindaya, Tenegüime, Timanfaya, Tinojay...), topónimos con morfema nominalizador de verbos am- (Masdache, Mafasca, Maninubre. Siguiendo su método rigurosamente filológico, redacté yo mi trabajo Morera (2011: 184-193).

42 "Sabemos —escribe Francisco Navarro (1990: 344)— que el guanche disponía de otras voces para significar 'harina gruesa de granos tostados', tales como ahorén/ ahoren; aramatanoque/ aramatonaque; aromatan/ asamatan/ azamotan". 
también trigo, millo, garbanzos...); y, en tercer lugar, porque este producto se integró en un sistema de alimentación distinto del aborigen, que fue el que trajeron los europeos ${ }^{43}$.

$\mathrm{Y}$, si con las palabras y las frases que conservamos de la lengua guanche no se puede reconstruir su sistema fonológico, el inventario de sus raíces y su sistema gramatical, nunca se podrá volver a hablar la lengua de la población preeuropea de las islas, porque lo que define a las lenguas naturales no son las palabras (que no son otra cosa que producto, ergon, como decía W. von Humboldt), sino el sistema (conjunto de fonemas, inventario de raíces, categorías, morfología y sintaxis) (energeia, decía el mencionado autor alemán), que permite formar palabras primitivas, palabras derivadas y palabras compuestas y organizarlas en estructuras complejas (oraciones), para dar forma al pensamiento y comunicarnos con nuestros semejantes.

\section{BIBLIOGRAFÍA}

Abreu Galindo, Fr. Juan de (1977): Historia de la conquista de las siete islas de Canaria, Alejandro Cioranescu (ed.), Santa Cruz de Tenerife, Goya Ediciones.

Almeida, Manuel y Carmen Díaz Alayón (1988): El español de Canarias, Santa Cruz de Tenerife, edición propia.

Alvar, Manuel (1993): Estudios canarios, II, Islas Canarias, Gobierno Autónomo de Canarias.

Alvar, Manuel (1959): El español hablado en Tenerife, Madrid, Consejo Superior de Investigaciones Científicas.

Álvarez Delgado, Juan (1981): Miscelánea guanche. Benahoare, Santa Cruz de Tenerife, Instituto de Estudios Canarios.

Álvarez Rixo, José Agustín (1991): Lenguaje de los antiguos isleños, Carmen Díaz Alayón y Antonio Tejera Gaspar (eds.), Santa Cruz de Tenerife, Centro de la Cultura Popular Canaria.

Berthelot, Sabino (1978): Etnografía y anales de la conquista de las Islas Canarias, Santa Cruz de Tenerife, Goya Ediciones.

Corominas, Joan, y José Antonio Pascual (1980-1991): Diccionario crítico-etimológico castellano e hispánico, Madrid, Gredos.

Cubillo Ferreira, Antonio (1980): Nuevo análisis de algunas palabras guanches: Estudio crítico, Las Palmas de Gran Canaria, Colección Guanche.

Díaz Alayón, Carmen, Francisco Javier Castillo y Gloria Díaz Padilla (1995): "La lengua de los aborígenes gomeros: de las fuentes más antiguas a los estudios más recientes", en Luis Fernández Pérez, Carmen Díaz Alayón, Francisco Javier Castillo y Gloria Díaz Padilla (eds.), Relación de palabras de la lengua indígena de La Gomera, Excelentísimo Cabildo Insular de La Gomera, pp. 15-72.

\footnotetext{
${ }^{43}$ En este sistema de alimentación, el gofio ("pan en esqueleto", como lo denominó Unamuno), que siguió usándose como base de la alimentación del español insular (entullo, en denominación de la sociedad hispano-canaria), pasó a consumirse acompañado de conduto (queso, higo pasado, cebolla, pejines, jareas, etc), mezclado con aceite y azúcar, frito, etc. Vid. Mora (1986) y Morera (2005b: 191-199).
} 
Espinosa, Fr. Alonso de (1980): Historia de nuestra señora de Candelaria, Alejandro Cioranescu (ed.), Tenerife, Goya Ediciones.

Glas, George (2010 [1764]): La historia del descubrimiento y la conquista de las Islas Canarias. Traducida de un manuscrito español, recientemente descubierto en la isla de La Palma, con un informe sobre el origen de los antiguos habitantes,traducción, introducción y notas de P. N. Leal Cruz, La Laguna/Tenerife/Islas Canarias, Centro de la Cultura Popular Canaria.

Hamouma, Hamid (1976): Manuel de grammaire berbère (kabyle), Paris, Association de Culture Berbère.

Hjelmslev, Louis, (1976): Principios de gramática general, Madrid, Gredos.

Lamano Beneite, José (1915): El dialecto vulgar salmantino, Diputación de Salamanca.

Louft, Abraham (2007): "Rasgos morfológicos de la toponimia no hispánica canaria vista desde el bereber", Almogaren, XXXVIII, pp. 69-112.

Louft, Abraham (2008): Curso sobre la lengua bereber, impartido en La Universidad de La Laguna durante los meses de abril y mayo.

Millares Torres, Agustín (1981 [1974]): Historia general de las Islas Canarias, Las Palmas de Gran Canaria, Edirca.

Mora, Manuel (1986): El libro del gofio, Tenerife, Ediciones Globo.

Morera, Marcial (1991a): “¿Qué conservan de la lengua guanche los guanchismos?”, Las hablas canarias. Cuestiones de lexicología, Puerto del Rosario, Centro de la Cultura Popular Canaria, pp. 41-65.

Morera, Marcial (1991b): “Grandeza y miseria del acervo léxico regional”, Las hablas canarias. Cuestiones de lexicología, Puerto del Rosario, Centro de la Cultura Popular Canaria, pp. 17-40.

Morera, Marcial (1991c): "El vocabulario de colores de cabra en Tindaya (Fuerteventura)", Las hablas canarias. Cuestiones de lexicología, Puerto del Rosario, Centro de la Cultura Popular Canaria, pp. 117-145.

Morera, Marcial (1993): "El mestizaje del vocabulario regional canario", La formación del vocabulario canario, Centro de la Cultura Popular Canaria, pp. 11-35.

Morera, Marcial (1995): "El vocabulario de colores de cabra en Lanzarote", Actas de las VI Jornadas de Estudios sobre Lanzarote y Fuerteventura, Arrecife, Cabildo Insular de Lanzarote, pp. 551-568

Morera, Marcial (2005a): "El estudio de los guanchismos. Consideraciones metodológicas", El habla canaria en la escuela, Puerto del Rosario, Cabildo Insular de Fuerteventura, pp. 117-153.

Morera, Marcial (2005b): "La geografía del gofio", El habla canaria en la escuela, Puerto del Rosario, Cabildo Insular de Fuerteventura, pp. 191-199.

Morera, Marcial (2007): Diccionario histórico-etimológico del habla canaria. Con ejemplos históricos y literarios, Puerto del Rosario, Cabildo Insular de Fuerteventura.

Morera, Marcial (2009): "La evolución lingüística de Canarias: del multilingüismo de los siglos XV y XVI al monolingüismo actual. Esbozo del problema", Letras de Deusto, 39,125, pp. 125-163.

Morera, Marcial (2011): "Consideraciones sobre los orígenes de la toponimia prehispánica", en Francisco Galante (dir.), Pájara. Territorio, memoria, identidad, Pájara, Ilustre Ayuntamiento de Pájara, pp. 184-193.

Navarro Artiles, Francisco (inédito): Campo semántico de los colores de cabra en Fuerteventura.

Navarro Artiles, Francisco (1981): Teberite. Diccionario de la lengua aborigen canaria, Las Palmas de Gran Canaria, Edirca.

Navarro Artiles, Francisco (1989): "Las 'marcas de ganado' en Fuerteventura”, III Jornadas de estudios de Fuerteventura, Puerto del Rosario, Cabildo Insular de Fuerteventura, pp. 321-345.

Navarro Artiles, Francisco (1990): "Consideraciones sobre los guanchismos en uso en el español hablado en Lanzarote y Fuerteventura", II Jornadas de historia de Lanzarote y Fuerteventura. Tomo II. Geografía, arte, prehistoria y lingüistica, Arrecife, Cabildo Insular de Lanzarote, pp. 341-360. 
Ortega Ojeda, Gonzalo e Isabel González Aguiar (2000): Diccionario de expresiones y refranes de Canarias, Las Palmas de Gran Canaria, Cabildo Insular de Gran Canaria.

Ramos Saavedra, J. L. (inédito): Estudio semántico del vocabulario de colores de ganado en El Hierro.

Real Academia (2001): Diccionario de la lengua española, Madrid, Espasa-Calpe.

Rohlfs, Gerhard (1954): "Contribución al estudio de los guanchismos de las Islas Canarias", Revista de Filología Española, XXXVIII, pp. 83-89.

Sabir, Ahmed (2001): Las Canarias preeuropeas y el norte de África. El ejemplo de Marruecos. Paralelismos lingüísticos y culturales, Rabat, edición propia.

Saussure, Ferdinand de (1973): Curso de lingüística general, Buenos Aires, Editorial Losada, S. A.

Sosa, Fr. José de (1994): Topografía de la isla afortunada de Gran Canaria (1678), Las Palmas, Cabildo Insular de Gran Canaria.

Trapero, Maximiano (1998): Los nombres guanches. Historia, filología y diletantismo, Las Palmas de Gran Canaria, UNED.

Trapero, Maximiano (1999): Pervivencia de la lengua guanche en el habla común de El Hierro. Léxico común y pastoril, de la flora y de la fauna y de la toponimia, Islas Canarias, Gobierno Autónomo de Canarias.

Trapero, Maximiano, y Elena Llamas Pombo (1998): “¿Es guanche la palabra guanche? Revisión histórica, filológica y antropológica de un tópico", Anuario de Estudios Atlánticos, XLIV, pp. 99-196.

Viana, Antonio de (1991 [1604]): Antigüedades de las Islas Canarias, M. R. Alonso (ed.), Islas Canarias, Biblioteca Básica Canaria.

Vicychl, Werner (1952): "La lengua de los antiguos canarios", Revista de Historia, Universidad de La Laguna, XVIII, pp. 167-204.

Viera y Clavijo, José de (1982a): Noticias de la historia general de las Islas Canarias, Santa Cruz de Tenerife, Ediciones Antonio de Bethencourt Massieu.

Viera y Clavijo, José de (1982b): Diccionario de historia natural de las Islas Canarias, Las Palmas, Cabildo Insular de Gran Canaria.

Wölfel, Dominik Josef (1996): Monumenta linguae canariae, Marcos Sarmiento Pérez (trad.), Islas Canarias, Gobierno Autónomo de Canarias.

Fecha de recepción: 3 de junio de 2013

Fecha de aceptación: 5 de noviembre de 2013 